UDC 621.01.62.50

N.P. Yaroshevich, Dr. Sc. (Tech.), Prof., orcid.org/0000-0002-2436-5608,

I.P.Zabrodets, orcid.org/0000-0001-6700-8400,

B. I. Dutchak, Cand. Sc. (Tech.), Assoc. Prof., orcid.org/0000-0002-1710-3423,

T. S. Yaroshevich, Cand. Sc. (Tech.), Assoc. Prof., orcid.org/0000-0001-8003-0514

\title{
START DYNAMICS OF VIBRATING MACHINES WITH UNBALANCED DRIVE CONSIDERING ITS ELASTICITY
}

Purpose. Investigation of start dynamic of the vibration machine with inertia vibration exciters considering the elastic connection of asynchronous electric motor rotors and unbalanced vibration exciter.

Methodology. Methods of applied theory of vibrations and method of direct division of motions are used for analytical research studies. The design of processes of running start of vibration machines is executed by using the numeral integration of equalizations of motions of the mechanical vibration system and equalizations of electromagnetic transients in asynchronous electric motors in the 'Maple' software environment.

Findings. It is shown that availability of elastic connection brings essential features to dynamics of vibration machine drive that should be considered when designing. Formulas for assessment of the starting deformation amplitudes and moments that occur in vibration machine drive coupling are obtained in an analytical form. It is demonstrated that oscillation amplitudes of elastic coupling at the start moment mostly depend on the remoteness of its own frequency from the current frequency in motor electricity network. An equation of coupling's torsional oscillations close to stationary rotation mode of unbalanced vibration exciter is obtained. Relation between oscillation of bearing vibration system and coupling's drive elasticity is revealed. It is found that during the start of vibration machines in case of Sommerfeld effect, resonant oscillation of elastic-damping elements (that connect motor and exciter rotors, which increase dynamic loads and energy losses in the system) excites, except resonant increase in braking vibration moment and "stopping" of engine speed.

Originality. Theoretical positions of dynamics of running approach of vibration machines with inertia drive considering elastic compounds of rotors of electrical motor with limited power and unbalanced vibration exciter power got their further development. It is found that if the spring element is in the drive, natural oscillation frequencies of vibration machine are added to its critical frequencies.

Practical value. The results of scientific work allow choosing options of vibration machines with unbalanced drive in a more reasonable way, which will reduce the amplitude of its start vibrations, dynamic loads and energy losses.

Keywords: vibration machine, unbalanced vibration exciter, elastic coupling, start of vibration machine, resonant oscillations, asynchronous motor

Introduction. Vibrating machines and devices are widely used in various industries [1-3]. The most common ones are vibrators with inertia drive due to simple design, a compact size with a large perturbing force. However, in transient modes of operation of such machines there may occur resonant vibrations, which are accompanied by a significant increase in dynamic loads on structural elements. For example, the practice of exploitation of vibroplatform of type SMJ, VB-15, VB-20 for volumetric compaction of concrete mixtures gives evidence of frequent failures of shafts which interconnect balance weights of separate vibroblocks. The construction of these shafts includes flexible couplings with elastic elements, which can be the main cause of destructive vibration.

Analysis of the recent research and publications. Start of the vibration machine with inertia drive has been investigated in several papers, e.g. $[1,4,5]$. Among recent works that addressed the problem of start-up of such machines articles [6, 7] are to be considered. However,

(C) Yaroshevich N. P., Zabrodets I. P., Dutchak B. I., Yaroshevich T . S., 2018 in these and other known publications on this issue, only dynamic models of machines with rigid links are used. In some works for computer simulation of dynamic processes in vibration machines with the inertial exciter and asynchronous electric motor a mathematical model is used taking into account elastic connection of the engine rotors and exciter. However, analysis of the influence on the dynamics of the machine of an elastic connection of the rotors has not been carried out. The methods of calculation of the elements of the vibrating machines with unbalanced drive are given in many works. However, in all of them the issues related to the couplings of the drive, are confined to a description of their design.

Description of the vibrating system and equations of motion. Currently, the most widely used are vibrators with flat character of oscillations of the working body. The considered vibrating system is a solid support associated with a fixed base with elastic damping elements (Fig. 1). On the carrier body there is set an unbalanced vibration exciter, which is driven in rotation by a motor of asynchronous type. However, the rotors of the motor 


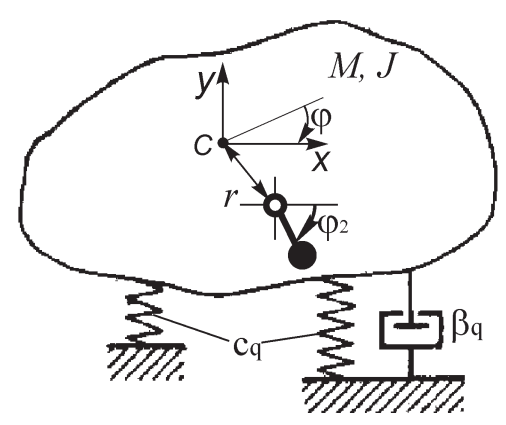

Fig. 1. Scheme of the vibration machine

and exciter are connected with flexible couplings, whose rigidity is substantially smaller than the stiffness of the rotor of the motor and the shaft of the exciter. We should note that in general, the rotors can be connected by any elastic-damping element (e.g. a belt drive). The oscillatory system is characterized by five generalized coordinates: the angles of rotation of the engine rotors $\varphi_{1}$, the agent $\varphi_{2}$ and carrier of the body $\varphi$ and its vertical and horizontal displacements $y, x$. The differential equation of motion of the system is written in the following form [8]

$$
\begin{gathered}
I_{1} \ddot{\varphi}_{1}+\beta_{c}\left(\dot{\varphi}_{1}-\dot{\varphi}_{2}\right)+c_{c}\left(\varphi_{1}-\varphi_{2}\right)=L_{1}-R_{1}\left(\dot{\varphi}_{1}\right) ; \\
I_{2} \ddot{\varphi}_{2}-\beta_{c}\left(\dot{\varphi}_{1}-\dot{\varphi}_{2}\right)-c_{c}\left(\varphi_{1}-\varphi_{2}\right)= \\
=-R_{2}\left(\dot{\varphi}_{2}\right)+m \varepsilon\left(\ddot{x} \sin \varphi_{2}+\ddot{y} \cos \varphi_{2}-\ddot{\varphi} r \sin \varphi_{2}+g \cos \varphi_{2}\right) ; \\
M \ddot{y}+\beta_{y} \dot{y}+c_{y} y=m \varepsilon\left(\ddot{\varphi}_{2} \cos \varphi_{2}-\dot{\varphi}_{2}^{2} \sin \varphi_{2}\right) ; \\
M \ddot{x}+\beta_{x} \dot{x}+c_{x} x+c_{x \varphi} \varphi=m \varepsilon\left(\ddot{\varphi}_{2} \sin \varphi_{2}+\dot{\varphi}_{2}^{2} \cos \varphi_{2}\right) ; \\
J \ddot{\varphi}+\beta_{\varphi} \dot{\varphi}+c_{\varphi} \varphi+c_{x \varphi} x=-m \varepsilon r\left(\ddot{\varphi}_{2} \sin \varphi_{2}+\dot{\varphi}_{2}^{2} \cos \varphi_{2}\right),
\end{gathered}
$$

where $I_{1}, I_{2}$ are given moments of inertia of the rotors of the engine and the exciter, accordingly; $m, \varepsilon$ stand for the mass of the exciter and eccentricity; $M, J$ are the mass and moment of inertia of the carrier body; $\beta_{c}, \beta_{x}$, $\beta_{y}, \beta_{\varphi}$ are the coefficients of the viscous friction of coupling and suspension springs of the carrier body; $c_{c}, c_{x}$, $c_{y}, c_{\varphi}$ are stiffness of the coupling and suspension; $r$ is the distance which determines the position of the axis of the exciter to the center of mass of the carrier body; $g$ is acceleration of free fall; $L_{1}, R_{i}\left(\dot{\varphi}_{i}\right)$ are points of the engine and the forces of resistance to rotation of the motor and exciter.

It should be noted that losses from friction in the bearings of the engine $R_{1}\left(\dot{\varphi}_{1}\right)$ are negligible (due to the rotor equilibrium). Therefore, they are neglected while analyzing the influence of the moment force of the balance weight on the dynamics of the system is not taken into account; since small oscillations are regarded, we consider that the coupling has a linear characteristic, the characteristics of the system dynamics with a nonlinear coupling are to be analyzed by numerical simulation.

Presentation of the main research. The most intense oscillations and, respectively, the maximum dynamic load in the drive vibrators occur during its running (coasting), in particular, at the moment of starting the engine and during the passage of the resonance frequencies of the carrier body. Let us consider these two periods of the system motion. To the study the first of them, we will describe the relative motion of the rotors of the engine and the vibration exciter connected by a coupling, using a single variable - the angle of twist of the coupling $\varphi_{12}$

$$
\begin{gathered}
\ddot{\varphi}_{12}+2 b_{c} \dot{\varphi}_{12}+p_{c}^{2} \varphi_{12}=\frac{L_{1}}{I_{1}}+ \\
+\frac{1}{I_{2}}\left[R_{2}\left(\varphi_{2}\right)-m \varepsilon\left(\ddot{x} \sin \varphi_{2}+\ddot{y} \cos \varphi_{2}-\ddot{\varphi} r \sin \varphi_{2}\right)\right], \\
\text { where } \varphi_{12}=\varphi_{1}-\varphi_{2} ; b_{c}=\beta_{c} \frac{I_{1}+I_{2}}{2 I_{1} I_{2}} ; \quad p_{c}=\sqrt{c_{c} \frac{I_{1}+I_{2}}{I_{1} I_{2}}} .
\end{gathered}
$$

In the considered class of vibrators ("soft isolated vibration"), run of their engine before reaching the zone of the resonant frequencies of the carrier body occurs fast enough. During this period, the frequency $\dot{\varphi}_{2}$ is still small enough and in the right part of equation (2) the second item can be neglected. The numerical estimation of its components counts in favor of this simplification of equation (2); so does the fact that vibrators with unbalanced drive are usually given the moment of inertia of the rotor of the electric motor which is much lower than the given moment of inertia of the exciter. Thus, a kind of motor starts without load occurs. Let us note that this start is inherent in many types of machinery (metal and woodworking machines, rolling conditions, and others); in this approach it is of no critical difference how many degrees of freedom a carrying system of the vibrator has, i. e., linear, flat or spatial fluctuations in operation. Thus, oscillatory processes arising in the drive at the moment of start, first of all, depend on the dynamics of the motor. Considering that at the initial moment of the start the induction motor has significant fluctuations of its magnetic moment with frequency close to the frequency of the current, the expression $L_{1}$ in the right part of (2) can be represented in the form $L_{1}=L_{\text {start }}\left(1-e^{-b_{\text {mot }} t} \cos \omega_{\text {cur }} t\right)$ (here $L_{\text {start }}$ is the starting torque of the engine; $b_{\text {mot }}$ is a coefficient characterizing the attenuation of the oscillations of the electromagnetic torque $\omega_{\text {cur }}=6.28 f_{\text {cur }} ; f_{\text {cur }}=50 \mathrm{~Hz}$ ) [9]. Thus, exploring the first of the selected periods of the start, we neglect the process of attenuation of these oscillations. This assumption is justified because a short period after switching on the motor is examined, where the fluctuations have no time to decrease significantly (in addition, their extinction is much slower than that of free oscillations of the actuator).

In this case, the general solution of the equations of the relative motion of the rotors of the engine and of the exciter (2) is presented as

$$
\varphi_{12}=\varphi_{s t}+A_{1} e^{-b_{c} t} \cos \left(p_{c} t+\alpha_{1}\right)+B_{1} \cos \left(\omega_{c u r} t-\beta_{1}\right),
$$

where $\varphi_{s t}=\frac{L_{s t a r t}}{c_{c}}$ is the angle of twist of the coupling under the action of a statically applied moment $L_{\text {start }}$ 
(static deformation); $A_{1}, \alpha_{1}$ is still integration; $B_{1}=$ $=\frac{L_{\text {start }}}{I_{1} \sqrt{\left(p_{c}^{2}-\omega_{c u r}^{2}\right)^{2}+4^{2} b_{c}^{2} \omega_{c u r}^{2}}} ; \operatorname{tg} \beta_{1}=\frac{2 b_{c} \omega_{c u r}}{p_{c}^{2}-\omega_{c u r}^{2}}$.

It is obvious that the steady-state oscillatory process is completely different in the pre- resonance and resonant fields. Naturally, significant differences exist in these cases for starting vibrations as well. First, let us consider the practically more interesting non-resonant cases (the natural frequency of the coupling $p_{c}$ is sufficiently far from the excitation frequency $\omega_{\text {cur }}$ ), for which resistance in the analysis of forced oscillations can be neglected. In this case, we write the solution (3) in the form

$$
\begin{gathered}
\varphi_{12}=\varphi_{s t}-e^{-b_{c} t}\left(\frac{L_{\text {start }}}{c_{c}}+B_{1}\right)\left[\frac{b_{c}}{p_{c}} \sin p_{c} t+\cos p_{c} t\right]+ \\
+B_{1} \cos \omega_{c u r} t
\end{gathered}
$$

where $B_{1}=-\frac{L_{\text {start }}}{c_{c}}\left(1-\frac{\omega_{\text {cur }}^{2}}{p_{c}^{2}}\right)^{-1}$.

Let us consider pre- and post resonance cases separately. Then $p_{\text {cur }} \gg \omega$, after simple transformations we obtain $\varphi_{12}=\varphi_{s t}\left(1-\cos \omega_{c u r} t\right)$. Thus, when switching the motor, starting fluctuations relative to the average angle of torsion $\varphi_{s t}$ with a relatively slowly damped amplitudes occur in the coupling (if you consider the process of damping oscillations of the electromagnetic torque of the motor) with frequency $\omega_{\text {cur }}$. An important thing in the case of the drive $p_{\text {cur }} \gg \omega_{\text {cur }}$ is that, a kind of "static application of the engine" torque occurs at which free oscillations are not excited, and transient oscillatory process is completely determined by the process of damping oscillations of the torque of the engine. The maximum value of the amplitude starting oscillation of the coupler will be approximately equal to the value of double static deformation; the magnitude of the damping in the coupling does not appreciably affect the flow of oscillatory processes in the drive. Thus, the duration of the start of oscillation of the actuator depends only on the duration of transient processes in the engine.

Taking into account (4), a moment $M_{c}=c_{c} \varphi_{12}+\beta_{c} \dot{\varphi}_{12}$ that occurs in the coupling immediately after starting the engine, can be determined by the formula

$$
M_{c} \approx L_{\text {start }}\left[1-\sqrt{1+\frac{4 h_{c}^{2} \omega_{\text {cur }}^{2}}{p_{c}^{2}}} \cos \left(\omega_{\text {cur }} t+\alpha\right)\right],
$$

where $\alpha=\arccos \left(\sqrt{1+\frac{4 h_{c}^{2} \omega_{c u r}^{2}}{p_{c}^{2}}}\right)^{-1} ; h_{c}=\frac{b_{c}}{p_{c}}$ is the relative damping coefficient.

Therefore, the maximum torque in the coupling will be at a level of $2 L_{\text {start }}$, its value will fluctuate with the frequency $\omega_{\text {cur }}$ relative to stable value, which equals the starting torque of the motor. Of course, in the case of the "so called static load" and a significant distance $p_{c}$ from$\omega_{\text {cur }}$ the fluctuation of the torque in the coupling would be the same as starting fluctuations of motor torque. Changes in damping ability of the coupler influence the value of the torque arising in it insignificantly, and do not affect the duration of his hesitation. At that time, reduction in the natural frequency of the coupling (approximation to $\omega_{\text {cur }}$ ) results in a considerable increase in the magnitude of the starting torque in the coupling.

Let us consider the post resonance case $p_{c} \ll \omega_{\text {cur }}$. The general solution of (3) is presented as

$$
\begin{gathered}
\varphi_{12}=\varphi_{s t}\left[1-e^{-b_{c} t} \sqrt{1+h_{c}^{2}} \cos \left(p_{c} t-\alpha\right)\right]+ \\
+\varphi_{s t} \frac{p_{c}^{2}}{\omega_{c u r}^{2}} \cos \omega_{c u r} t .
\end{gathered}
$$

The expression (5) shows that immediately after starting the engine a distinct transition process will occur in the coupling. It is completely determined by the first term (5) and is a damped oscillation of the cover coupling with the natural frequency $p_{c}$. Numerical analysis (5) allows concluding that in the case of low damping capacity of the coupling, the maximum oscillation amplitude will be no more than half the value of its static deformation. The increase in the coefficient of viscous friction coupling reduces the amplitudes and duration of vibrations. According to (5), they quickly fade and further occur with a frequency $\omega_{\text {cur }}$ significantly smaller than $\varphi_{s t}$ amplitude $A=\frac{L_{\text {start }}}{c_{c}} \frac{p_{c}^{2}}{\omega_{c u r}^{2}} ;$ the duration of the latter is insignificant, while it does not depend on the damping capacity of the coupling, and is determined only by the duration of the start of oscillations of the electromagnetic torque.

Similar conclusions can be drawn regarding the changes of moment that occurs in the coupling at startup in the case $p_{c} \ll \omega_{c u r}$. Taking into account (5), its magnitude at the initial and following periods of startup can be estimated by the formula

$$
\begin{gathered}
M_{c}=L_{\text {start }}\left[1-e^{-b_{c} t} \sqrt{\left(1+h_{c}^{2}\right)\left(1+4 h_{c}^{4}\right)} \cos \left(p_{c} t+\alpha_{1}\right)\right] ; \\
M_{c}=L_{\text {start }}\left(1-\frac{2 b_{c}}{\omega_{\text {cur }}} \sin \omega_{\text {cur }} t\right),
\end{gathered}
$$

where $\alpha_{1}=\arccos \frac{1-2 h_{c}^{2}}{\sqrt{1+4 h_{c}^{4}}}$.

According to the first expression (6), the maximum amplitude can reach values of more than two starting points of the motor for greater resistance $\left(h_{c}>0.8\right)$; at low and intermediate resistance values on the level $1.5 L_{\text {start }}$. Such relatively large starting amplitude fades away quite rapidly. The following start-up period, according to the second expression (6), their value will be significantly lower than $L_{\text {start }}$.

In the resonant case $\left(p_{c}=\omega_{\text {cur }}\right)$ the general solution of (3) will be presented in the form

$$
\begin{gathered}
\varphi_{12}=\varphi_{s t}\left(1-\frac{1}{2 h_{i}} e^{-b_{c} t} \sqrt{1+8 h_{c}^{2}+4 h_{c}^{4}} \cos p_{c} t+\right. \\
\left.+\frac{1}{2 h_{c}} \sin \omega_{c u r} t\right) .
\end{gathered}
$$

ISSN 2071-2227, Naukovyi Visnyk NHU, 2018, № 3 
Then, the expression by which it is possible to estimate the initial deformation of the coupling and the amplitude of time arising in it (given the fact that free vibrations decay fast enough), is written in the form

$$
\begin{gathered}
\varphi_{12}=\varphi_{s t}\left(1-\frac{1}{2 h_{c}} \sin \omega_{c u r} t\right) \\
M_{c}=L_{\text {start }}\left[1-\frac{1}{2 h_{c}} \sqrt{1+h_{c}^{2}} \sin \left(\omega_{\text {cur }} t+\alpha_{2}\right)\right],
\end{gathered}
$$

where $\alpha_{2}=\arccos \frac{1}{\sqrt{1+4 h_{c}^{2}}}$.

Analysis of expression (7) shows that for small coefficients of viscous friction $\left(h_{c}<0.3\right)$, the maximum deformation of the coupling and the value of arising torque in it can be relatively large - at times more than a static applied starting torque. Certainly, in the case of high friction, even in case $p_{c} \approx \omega_{\text {cur }}$, their amplitude values will not be resonant.

We should note that to simplify the above the limited cases were considered. Obviously, when the frequencies $p_{c}$ and $\omega_{\text {cur }}$ do not differ so much, in the case of $p_{c} \approx \omega_{\text {cur }}$, formulated regularities are preserved in the form of a certain trend.

Modeling of vibrator start-up. Numerical integration of system (1) is made with the following basic parameters: $M=330 \mathrm{~kg} ; J=10.5 \mathrm{~kg} \cdot \mathrm{m}^{2} ; I_{1}=0.004 \mathrm{~kg} \cdot \mathrm{m}^{2} ; I_{2}=$ $=0.04 \mathrm{~kg} \cdot \mathrm{m}^{2} ; m=35 \mathrm{~kg} ; \varepsilon=0.033 \mathrm{~m} ; c_{y}=c_{x}=5 \times$ $\times 10^{5} \mathrm{~N} / \mathrm{m} ; c_{\varphi}=2.1 \cdot 10^{4} \mathrm{~N} / \mathrm{m} ; \beta_{y}=\beta_{x}=1.8 \cdot 10^{3} \mathrm{~kg} / \mathrm{s} ;$ $\beta_{\varphi}=180 \mathrm{~kg} \cdot \mathrm{m}^{2} / \mathrm{s} ; P_{\text {mot }}=1.5 \mathrm{~kW}, n_{\text {nom }}=1415 \mathrm{rot} / \mathrm{min}$ (used for modeling, the so-called $A$-model of the asynchronous motor [9]).

As shown in Fig. 2, $a$, in the case of $p_{c} \gg \omega_{c u r}$ $\left(\frac{p_{c}}{\omega_{c u r}}=2.5\right)$, when the engine is turning in the coupling there arise monoharmonic damped vibrations of its Halfmuff with a frequency $\omega_{c u r}$ relative to the average angle of twist $\varphi_{s t}$. Let us pay attention to the fact that the oscillatory process in Fig. 2, $a$ copies the process of vibration damping of engine torque (Fig. 3, curve 1). An increase in the damping capacity of the coupling slightly reduces the amplitude of its oscillation and does not affect their duration, which is determined only by the duration of transient processes in the engine. The maximum deformation of the coupling is approximately equal to $2 \varphi_{s t}$.

According to Fig. 3, the curves of starting points of the engine and coupling practically overlap: the maximum value of the moments is around $2 L_{\text {start }}$, while they oscillate with a frequency $\omega_{\text {cur }}$ of relatively stable values $L_{\text {start }}$. Changes in damping ability of the coupling slightly influence the course of oscillatory processes, when an approximation $p_{c}$ to $\omega_{c u r}$ the frequency leads to a substantial increase in arising value of the torque in it. Moreover, its amplitudes become larger than amplitude of the motor torque; impact resistance coupling becomes significant.

In post resonance case $p_{c} \ll \omega_{c u r}\left(\frac{\omega_{c u r}}{p_{c}}=2.5\right)$ in the coupling immediately after starting of the engine there

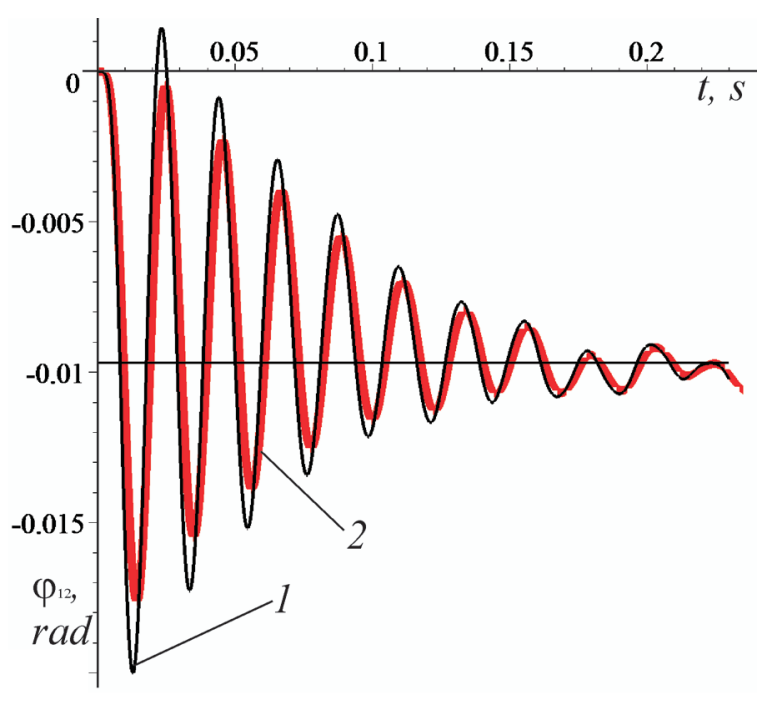

$a$

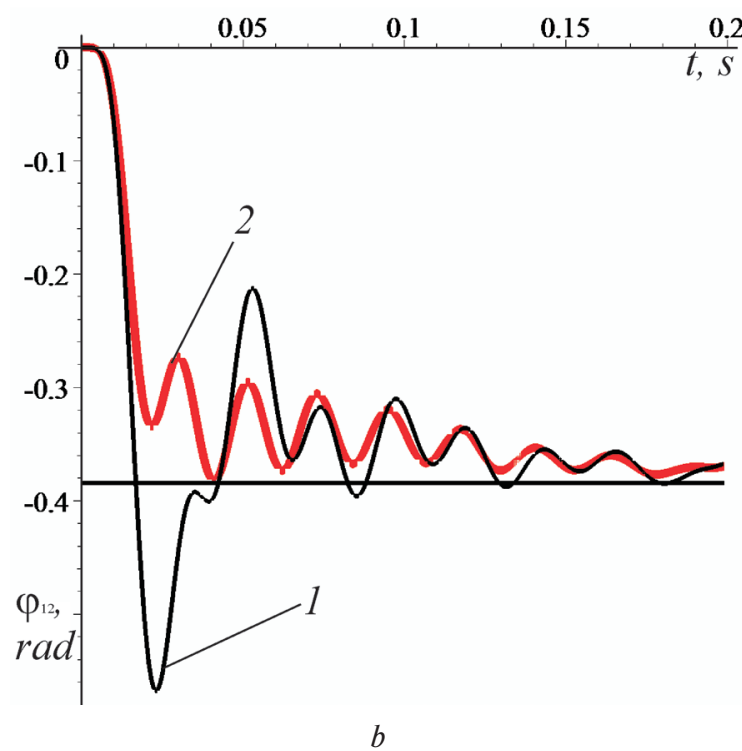

Fig. 2. Time variations of the torsional deformation of the coupling during startup:

$a-\omega_{\text {cur }} \ll p_{c}=785 s^{-1} ; b-\omega_{\text {cur }} \gg p_{c}=125 s^{-1} ; 1-h_{c}<0.3$; $2-h_{c}=0.9$, (horizontal line $\left.-\varphi_{s t}\right)$

occurs an oscillatory process with the fundamental frequency $p_{c}$ (Fig. 2,b) which rapidly fades to the relatively small amplitudes. Maximum start amplitude of these oscillations reaches a value $1.5 \varphi_{s t}$. When you increase the coefficient of viscous friction of the coupling, they significantly reduce and at the time of start-up become lower than $\varphi_{s t}$. The greatest values of the torque that occurs in the coupling at start-up do not exceed the limits $2 L_{\text {start }}$ (Fig. 4); however, they fade quite quickly. Let us note that in the case $p_{c} \ll \omega_{c u r}$ fluctuations of torque in the coupling are much lower than launcher fluctuations of engine torque. The increase in natural frequency of the coupling (its approach to $\omega_{\text {cur }}$ ) leads to an increase in oscillations arising in it; and the magnitude of its amplitude obtains greater value than the amplitude of the motor torque.

In the resonant case $\left(p_{c} \approx \omega_{\text {cur }}\right)$, for small coefficients of friction $\left(h_{c} \leq 0.3\right)$, a process of growing deformation 


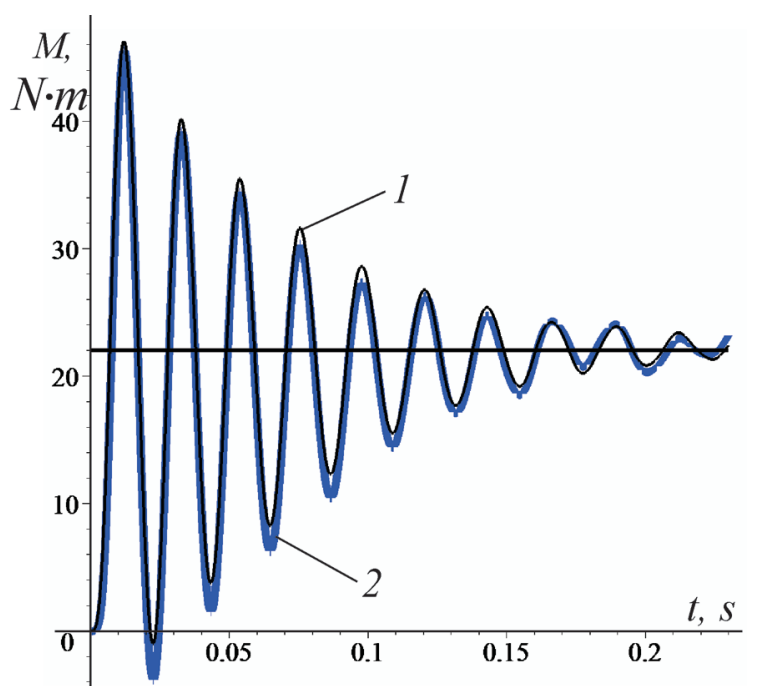

Fig. 3. Temporal changes in the engine torque (1) and the moment the coupling (2) in case $\omega_{\text {cur }} \ll p_{c}=785 \mathrm{~s}^{-1}$; $h_{c}=0.3$, (horizontal line $\left.-L_{\text {start }}\right)$

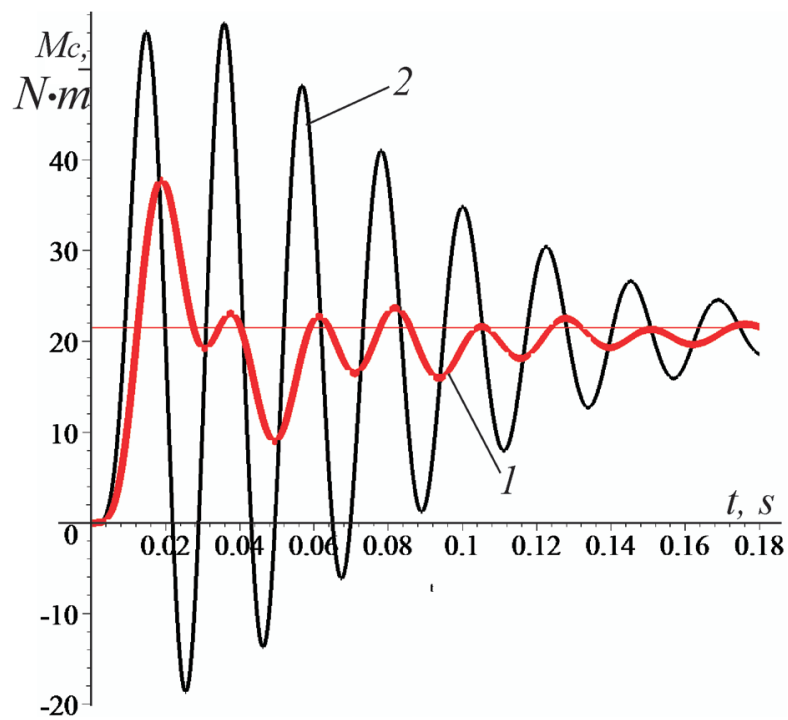

Fig. 4. Temporal changes in torque in the coupling $\left(h_{c}<\right.$ $<0.3)$ :

$1-\omega_{\text {cur }}>p_{c}=125 s^{-1} ; 2-\omega_{\text {cur }} \approx p_{c}=310 s^{-1}$

of the coupling and the value of the arising torque occurs immediately after starting (Fig. 4, curve 2). However, this increase is relatively short, and the maximum amplitude of the torque in the coupling does not exceed $2.5 L_{\text {start }}$. In the case of large friction, the resonant growth of the time the coupling is hardly observed.

The motion during the passage of the resonance frequencies of the carrier body. To study this period of motion, we use the method of direct separation of motions [1]. Then the solution of system (1) can be represented as

$$
\varphi_{i}=\omega t+\alpha_{i}(t)+\psi_{i}(t, \omega t) ; \quad q_{i}=q_{i}(t, \omega t),
$$

where $\omega$ is some previously unknown frequency at which there is a "stuck" of rotor speed; $\alpha_{i}(t)$ is slow, but $\psi_{i}$ and $q_{i}=x, y, \varphi$ are fast $2 \pi$-periodic functions of time, and their average values for the period are equal to zero; we also assume that $\dot{\psi}_{i} \ll \omega$. Assumptions, regarding slow changes, is adopted in the sense that $\dot{\alpha}_{i} \ll \omega$.

Let us note that the application of the method is guaranteed even for the relatively large $\omega$, at least near stationary regimes $\alpha_{i}=$ const [1], which will be discussed below; the study of such modes ("stuck" motor speed maximum loaded mode as well as superresonance established mode - operating mode) is the most interesting practically.

Following the procedure of the method, it is easy to come to a system of equations with slow and fast movements of the rotors of the engine and the exciter in the form [1]

$$
\begin{gathered}
I_{1} \ddot{\alpha}_{1}+\beta_{c} \dot{\alpha}_{12}+c_{c} \alpha_{12}+k_{1} \dot{\alpha}_{1}=L_{1}(\omega) ; \\
I_{2} \ddot{\alpha}_{2}-\beta_{c} \dot{\alpha}_{12}-c_{c} \alpha_{12}+k_{2} \dot{\alpha}_{2}=-R_{2}(\omega)+V(\omega) ; \\
I_{1} \ddot{\psi}_{1}+\beta_{c} \dot{\psi}_{12}+c_{c} \psi_{12}=\mu \Psi_{1} ; \\
I_{2} \ddot{\psi}_{2}-\beta_{c} \dot{\psi}_{12}-c_{c} \psi_{12}=\mu \Psi_{2},
\end{gathered}
$$

where $\quad \dot{\alpha}_{12}=\dot{\alpha}_{1}-\dot{\alpha}_{2} ; \quad \dot{\psi}_{12}=\dot{\psi}_{1}-\dot{\psi}_{2} ; \quad \mu \Psi_{1}=-k_{1} \dot{\psi}_{1}$; $\mu \Psi_{2}=\Phi\left(\ddot{q}_{i}, \varphi_{2}\right)-k_{2} \dot{\Psi}_{2} ; \quad \Phi\left(\ddot{q}_{i}, \varphi_{2}\right)=m \varepsilon\left(\ddot{x} \sin \varphi_{2}+\right.$ $\left.+\ddot{y} \cos \varphi_{2}-\ddot{\varphi} r \sin \varphi_{2}+g \cos \varphi_{2}\right) ; \quad V(\omega)=\frac{\omega}{2 \pi} \int_{0}^{2 \pi / \omega} \Phi\left(\ddot{q}_{i}, \varphi_{2}\right) d \tau$

is the so-called vibratory moment [1], which is an additional dynamic load on the engine caused by fluctuations of the carrier body on which the vibration exciter is installed.

We should note that while obtaining the system of equations (8), linearization of the expressions $L_{1}=$ $=L_{1}\left(\dot{\varphi}_{1}\right), R_{i}\left(\dot{\varphi}_{i}\right)$ as in [1] was performed close to the stationary values $\dot{\varphi}_{i}=\omega$, where $k_{1}, k_{2}$ are the damping coefficients. In equations (9) the value $\mu>0$ is considered as a small parameter (taking into account the proximity of the investigated stationary regimes to uniform rotation, and the fact that the uneven rotation of the rotors is invoked primarily by the oscillations of the axes of vibration exciters and the action of torques the balance weight).

The magnitude of the vibratory moment for the considered vibrating system can be determined by the formula

$$
V(\omega)=-\frac{1}{2} \omega \sum_{q_{i}=x, y, \varphi} A_{q}^{2} \beta_{q}
$$

where $A_{q}=\frac{m \varepsilon \omega^{2}}{M \sqrt{\left(\omega^{2}-p_{q}^{2}\right)^{2}+4 b_{q}^{2} \omega^{2}}}$ is the amplitude of forced oscillations of the carrier body in a stationary mode; $p_{q}$ is the frequency of natural oscillations of elastic suspended from the carrier body; $b_{q}=\frac{\beta_{q}}{2 M_{q}}$ (if $q=x$, $y$ then $M_{q}=M$; if $q=\varphi$ then $\left.M_{q}=J\right)$.

According to (10), in the case of resonant growth of the oscillation amplitude of the resonance, the load on the engine increases.

For stationary modes (8) we will present the system in the form 


$$
\begin{gathered}
c_{c}\left(\alpha_{1}-\alpha_{2}\right)=L_{1}(\omega) ; \\
c_{c}\left(\alpha_{1}-\alpha_{2}\right)=-R_{2}(\omega)+V(\omega) .
\end{gathered}
$$

From (11) we see that during the "stuck" speed of the engine in the area of the resonant frequencies of the carrier body, the average values of the twist angle of the sleeve and the torque emerging in it (its elastic component) take values somewhat larger than their average values at start (respectively $\alpha_{12} \approx \frac{L_{\max }}{c_{c}}, M_{e l}=c_{c} \alpha_{12} \approx L_{\max }$, where $L_{\max }$ is the maximum (critical) drive moment). Therefore, in the case of the Sommerfeld effect, the total resistance moment on the motor shaft is approximately equal to its maximum torque. As a result, the running vibration exciter is suspended.

According to equations (9), the intense vibrations can excite the drive of the vibrator during the passage of areas of natural frequencies of its carrier body. Therefore, it can be expected that more pronounced manifestation of the resonant mode occurs at the level of fast movements. Let us turn to the corresponding equations (9). In the present method, they can be solved approximately. Looking for solvation (9) in the form of a series in powers of the small parameter $\psi_{i}=\psi_{i}^{(0)}+\mu \psi_{i}^{(1)}+\ldots$, we write the equation of relative rapid fluctuations of the engine and the exciter close to stationary regimes in the form

$$
\begin{gathered}
\ddot{\psi}_{12}+2 b_{c} \dot{\psi}_{12}+p_{c}^{2} \psi_{12}=\frac{F}{2 I_{2}} \sum_{q_{i}=x, y, \varphi} A_{q} \sin \left(2 \omega t+\alpha_{q}\right)+ \\
+\frac{m \varepsilon g}{I_{2}} \cos \left(\omega t+\alpha_{2}\right)
\end{gathered}
$$

where $F=m \varepsilon \omega^{2}$.

It should be noted that in (12), and below, the values of phase shift $\alpha_{q}$ are not critical.

The solution of equation (12), given the fact that free vibrations decay fast enough and can be neglected, is presented in the form

$$
\begin{aligned}
\psi_{12}= & \frac{F}{2 I_{2} \sqrt{\left(p_{c}^{2}-4 \omega^{2}\right)^{2}+16 b_{c}^{2} \omega^{2}}} \sum_{q_{i}=x, y, \varphi} A_{q} \sin 2 \omega t+ \\
& +\frac{m \varepsilon g}{I_{2} \sqrt{\left(p_{c}^{2}-\omega^{2}\right)^{2}+4 b_{c}^{2} \omega^{2}}} \cos \left(\omega t+\beta_{g}\right) .
\end{aligned}
$$

Analysis of the solution (13) of equations of relative torsional vibration of the coupling elements near the stationary modes of motion gives evidence of the following:

- dependence of amplitude of coupling (frequency $\omega, 2 \omega)$ on the frequency of rotation of vibration exciter has resonance character;

- resonance increase in the amplitude of the oscillations except in the case of coincidence (proximity) of the natural frequency of the coupling $p_{c}$ (multiple frequencies) and frequency of rotation of the pathogen may occur near the natural frequencies of the carrier body $p_{q}$. In this case, in the coupling the amplitude of the oscillations moment arising in it increases with resonance (its elastic component and the viscous forces of resistance); consequently, the dynamic loads in the drive increases as well as the unevenness of rotation of the rotor and loss of energy. Thus, the elastic drive elements (resonance oscillations) may increase the additional load on the engine provoking Sommerfeld effect.

Typically, elastic couplings of machine drives satisfy the condition of vibration isolation, which is determined by inequality $\frac{\omega_{o}}{p_{c}}>\sqrt{2}$ ( $\omega_{o}$ is operating frequency). That is, the couplings are usually quite "soft" $p_{c} \ll \omega_{o}$ (so far as the strength condition). At the same time, the passage by unbalance vibration exciter of frequency $p_{c}$ at start must happen quickly. At the same time, we know that quick passage by the vibration exciter of the carrier body $p_{q}$ own frequencies is not always possible, and may even be "stuck" of its speed in the field $p_{q}$. Then resonant vibrations of the carrier body will be excited. According to (13), there will be resonant increase in the amplitude of torsional vibrations of the coupling. Greater fluctuations in the couplings will occur when $p_{q}$ and $p_{c} / 2$ frequencies are close, which is highly probable for the drive of the considered soft vibration isolated machinery $\left(p_{c} \ll \omega_{o}\right)$ with "soft" couplings. Therefore, at the startup of vibrator with unbalance drive and "soft" coupling, there is risk of significant resonant oscillations of the coupling. To avoid this, first, we can recommend a sufficient distance of $p_{q}$ and $p_{c} / 2$ frequencies (at least $\left.\frac{p_{c}}{2 p_{q}}>1.25\right)$. Certainly, while selecting the parameters of the vibration machine, one should not overestimate the frequency $p_{q}$ (which facilitates the passage zone of the resonance), as well as not to underestimate the frequency $p_{c}$.

Thus, at starting the vibrators in case of manifestation of the effect of Sommerfeld, except for the resonant growth of brake vibration torque and "stuck" of engine speed, there excite resonance oscillations of elasticdamping elements connecting the rotors of the motor and exciter which increase dynamic loads and energy losses in the system. From the above it follows that the "hard" couplings have advantages when used in a vibration machine drive.

We should note that the reduction of the amplitude of the coupling in the resonance region can be achieved (except by changing its parameters) by reduction of natural frequencies of the vibrator, by increasing the damping of fluctuations of the carrier body and its mass.

The effect of resonance oscillations of the coupling during the passage zone of the natural frequencies of the carrier body is well visible in Fig. 5, which is obtained as a result of numerical integration of equations (1). Graphs show a resonant increase in the amplitude of the rotary oscillations $\varphi_{12}$ (with frequency $2 \omega \approx 109.7 \mathrm{~s}^{-1}$ ) of the coupling and the torque arising in it with "stuck" of the motor speed in the area of self-frequency carrier system $p_{q}$ for the case of its relative proximity to the frequency $p_{c} / 2\left(p_{x}=p_{y}=57.7 \mathrm{~s}^{-1}, p_{\varphi}=58.9 \mathrm{~s}^{-1}\right.$ and $p_{c} / 2=$ $=58.4 \mathrm{~s}^{-1}$ ) while at start-up without the "stuck" speed (the static moments of balance weight are reduced from $m \varepsilon=0.54 \mathrm{~kg} / \mathrm{m}$ to $m \varepsilon=0.42 \mathrm{~kg} / \mathrm{m}$ for other similar pa- 


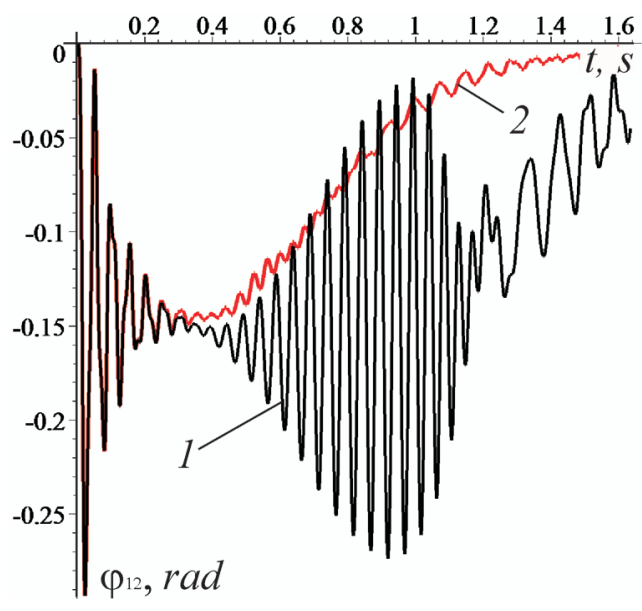

$a$

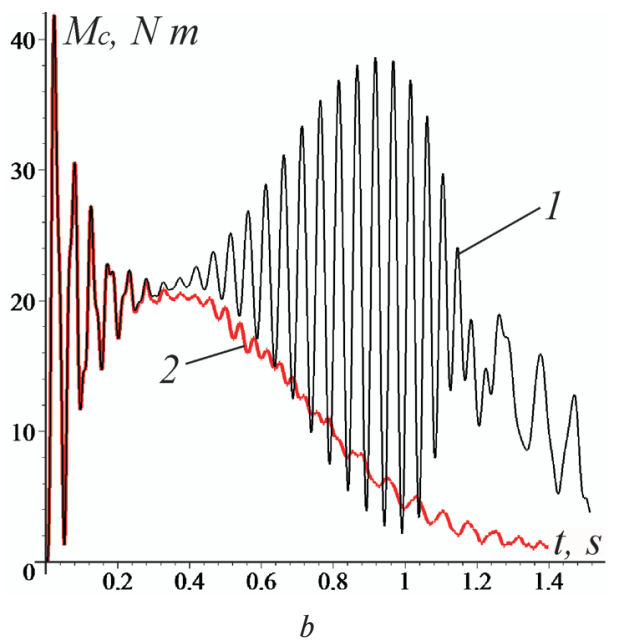

Fig. 5. Changes in time:

$a$ - amplitude of torsional vibration coupling; $b$ - the moment in the coupling, in case: 1 - the manifestation of the Sommerfeld effect; 2 - no effect

rameters). A resonant increase in the amplitudes of the oscillations is not observed (Fig. 5, curve 2). Despite the "stuck" of speed of the engine it is important that there is no substantial growth of the amplitude of the coupling and the torque arising in it also in the case of the relative distance of frequency $p_{q}$ and $p_{c} / 2$.

Conclusions. The amplitudes and duration of vibrations of an elastic coupling of the drive of the vibration machine at the time of start, first of all, depend on how distant is its own frequency from the frequency of the current in the power supply of the engine. In case of remoteness of the starting frequency, fluctuations will be relatively small and quickly fade regardless of the damping capacity of the coupling. In case of closeness of $p_{c}$ and $\omega_{\text {cur }}$ the fluctuations are considerably large, especially for small resistance, but their duration is in any case minor and determined by the duration of the start of oscillations of the torque of the engine. Thus, the amount of deformation of the coupling and the torque arising in it do not have time to obtain values that are significantly larger than their double static value.

A resonant increase in the amplitude of vibrations of elasto-damping elements of the actuator except in the case of coincidence (proximity) of the frequency of its own fluctuations $p_{c}$ (multiple frequencies) and frequency of rotation of the pathogen may occur near the natural frequencies of the carrier body $p_{q}$. In the case of a "stuck" motor speed in the area $p_{q}$ of arising resonant vibrations of the drive are more dangerous than those which are generated at the time of start-up: at approximately the same amplitude, their duration can be significantly greater. To avoid resonant oscillations of an elastic coupling in the area $p_{q}$ we should primarily provide sufficient distance of $p_{q}$ and $p_{c} / 2$ own frequencies from each other.

\section{References.}

1. Blekhman, I. I., 2013. Theory of vibration processes and devices. Vibration mechanics and vibration technology. St. Petersburg: The Publishing House "Ore and Metals". 2. Li, Y., Li, H., Wei, X. and Wen, B., 2015. Verification of self-synchronism of a nonlinear oscillatory system with double homodromy rotors. In: IEEE International Conference on Mechatronics and Automation, pp. 1911-1916. 3. Michalczyk, J. and Pakuła, S., 2016. Phase control of the transient resonance of the automatic ball balancer. Mechanical Systems and Signal Processing, 72-73, pp. 254-265.

4. Kuzio, I. V., Lanets, O. V. and Gurskyi, V. M., 2013. Synthesis of low-frequency resonance vibratory machines with an aeroinertia drive. Naukovyi Visnyk Natsionalnoho Hirnychoho Universytetu, 2, pp. 37-45.

5. Hou, Y., Fang, P., Du, M. and Nan, Y., 2016. Synchronization Investigation Of Vibration System Of Two Co-Rotating Rotor With Energy Balance Method, $A d-$ vances in Mechanical Engineering, 8(1), pp. 1-19.

6. Blekhman, I. I., Vasil'kov, V. B. and Yaroshevych, N. P., 2013. On Some Opportunities for Improving Vibration Machines with Self-Synchronization Inert, Vibration Exciters Journal of Machinery Manufacture and Reliability, 42(3), pp. 192-195.

7. Filimonikhin, G. B. and Yatsun, V.V., 2016. Investigation of the process of excitation of two frequency vibrations by ball auto-balancer of Gil 42 screens. Eastern-European Journal of Enterprise Technologies, 1(7(79)), pp. 17-23.

8. Blekhman, I. I., 2015. Self-synchronism in nature and technique. Moscow: LENAND.

9. Tchaban, V. and Lyshuk, V., 2013. Mathematical model vnit power asynchronous machines. Lutsk: LNTU.

10. Yaroshevich, N. P. and Silivoniuk, A. V., 2013. On some features of run-up dynamics of vibration machines with self-synchronizing inertion vibroexciters. Naukovyi Visnyk Natsionalnoho Hirnychoho Universytetu, 4, pp. 70-75.

\section{Динаміка пуску вібраційних машин з дебалансним приводом з урахуванням його пружності}

\section{М. П. Ярошевич, І. П. Забродець, Б. І. Дутчак, Т. С. Ярошевич}

Луцький національний технічний університет, м. Луцьк, Україна, e-mail: yaroshevichmp@gmail.com 
Мета. Дослідження динамічних процесів при пуску вібраційної машини з дебалансним віброзбудником коливань з урахуванням пружності його з'єднання з ротором асинхронного електродвигуна.

Методика. Для аналітичних досліджень використані методи прикладної теорії коливань, підхід вібраційної механіки й метод прямого розділення рухів. Моделювання процесу пуску вібромашини полягало у спільному чисельному інтегруванні диференціальних рівнянь руху механічної коливальної системи та динамічної моделі асинхронного електродвигуна за допомогою програмного продукту Maple.

Результати. Показано, що наявність пружного з'єднання вносить істотні особливості в динаміку привода вібромашин, що потрібно враховувати при ïx проектуванні. В аналітичній формі отримані формули, котрі дозволяють оцінити амплітуди пускових деформацій і моментів, що виникають у муфті привода. Продемонстровано, що амплітуди коливань пружної муфти в момент пуску, здебільшого, залежать від віддаленості іiі власної частоти від частоти струму в мережі живлення двигуна. Отримані рівняння крутильних коливань муфти поблизу стаціонарних режимів обертання дебелансного збудника (що у т. ч. враховує випадок „застрягання“" швидкості двигуна в зоні резонансних частот вібромашини). Виявлено взаємозв'язок коливань несучої системи вібромашини та пружної муфти привода. Встановлено, що при пуску вібромашин у разі прояву ефекту Зоммерфельда, крім резонансного зростання гальмівного вібраційного моменту й „застрягання“ швидкості двигуна, збуджуються резонансні коливання пружно-демпфуючих елементів, що з'єднують ротори двигуна та збудника, які збільшують динамічні навантаження й втрати енергії в системі.

Наукова новизна. Отримали подальшого розвитку теоретичні положення динаміки пуску вібраційних машин з інерційним приводом з урахуванням пружності з'єднання роторів електродвигуна обмеженої потужності й дебалансного віброзбудника. Встановлено, що за наявності у приводі пружного елемента до його критичних частот добавляються частоти власних коливань вібромашини.

Практична значимість. Результати роботи дозволяють більш обгрунтовано вибирати параметри вібраційних машин з дебалансним приводом, що дозволить зменшувати амплітуди його пускових коливань, динамічні навантаження та втрати енергії.

Ключові слова: вібраційна машина, дебалансний віброзбудник, пружна муфта, пуск вібромашини, резонансні коливання, асинхронний електродвигун

\section{Динамика пуска вибрационных машин с дебалансным приводом с учетом его упругости}

\author{
Н. П. Ярошевич, И. П. Забродеи, Б. И. Дутчак, \\ Т. С. Ярошевич
}

Луцкий национальный технический университет, г. Луцк, Украина, e-mail: yaroshevichmp@gmail.com

Цель. Исследование динамических процессов при пуске вибромашины с дебалансным вибровозбудителем с учетом упругости его соединения с ротором асинхронного двигателя.

Методика. Для аналитических исследований использованы методы прикладной теории колебаний, подход вибрационной механики и метод прямого разделения движений. Моделирование процесса пуска вибромашины состояло в численном интегрировании уравнений движения механической колебательной системы и динамической модели асинхронного двигателя с помощью программного продукта Maple.

Результаты. Показано, что наличие упругого соединения вносит существенные особенности в динамику привода вибромашин, которые нужно учитывать при их проектировании. В аналитической форме получены формулы, позволяющие оценить амплитуды пусковых деформаций и моментов, возникающих в муфте привода. Продемонстрировано, что амплитуды колебаний упругой муфты в момент пуска, в основном, зависят от удаленности ее собственной частоты от частоты тока в сети питания двигателя. Получено уравнение крутильных колебаний муфты вблизи стационарных режимов вращения вибровозбудителя (которое учитывает в т.ч. случай „застревания“ частоты двигателя в зоне резонанасных частот вибромашины). Обнаружена взаимосвязь колебаний несущей системы машины и муфты привода. Установлено, что при пуске вибомашин в случае проявления эффекта Зоммерфельда, кроме резонансного возрастания вибрационного момента и „застревания" скорости двигателя, возбуждаются резонансные колебания упруго-демпфирующих элементов, соединяющих роторы двигателя и возбудителя, которые увеличивают динамические нагрузки и потери энергии в системе.

Научная новизна. Получили дальнейшее развитие теоретические положения динамики пуска вибрационных машин с инерционным приводом с учетом упругости соединения роторов электродвигателя ограниченной мощности и дебалансного вибровозбудителя. Установлено, что при наличии в приводе упругого элемента к его критическим частотам добавляются частоты собственных колебаний вибромашины.

Практическая значимость. Результаты работы позволяют более обоснованно выбирать параметры вибромашин с дебалансным приводом, что позволит уменьшать амплитуды пусковых колебаний, динамические нагрузки и потери энергии.

Ключевые слова: вибромашина, дебалансный вибровозбудитель, упругая муфта, пуск вибромашины, резонансные колебания, асинхронный двигатель

Рекомендовано до публікації докт. техн. наук B. I. Шваб’юком. Дата надходження рукопису 02.04.17. 